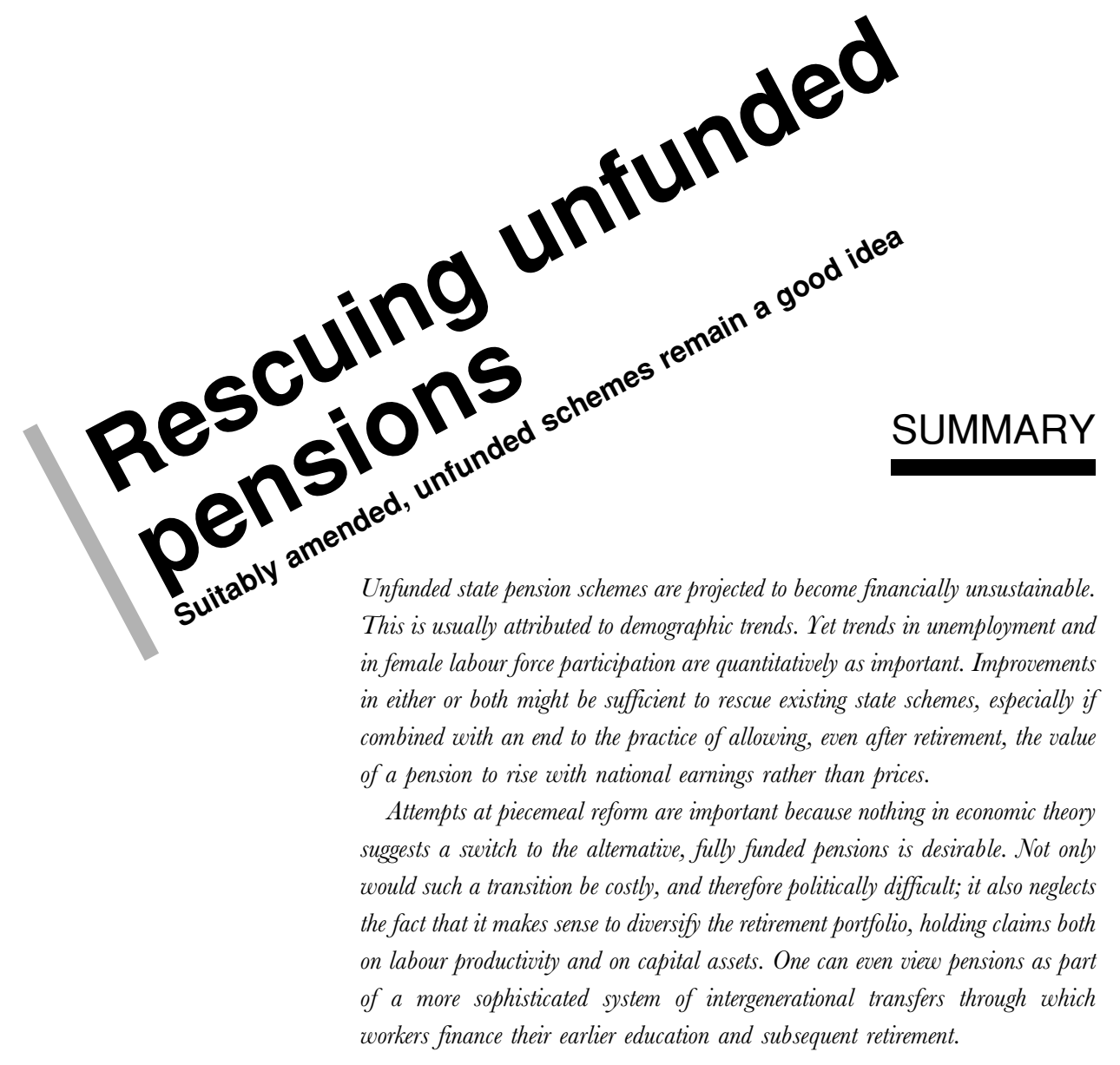

Michele Boldrin, Fuan 7. Dolado, Fuan F. Fimeno and Franco Peracchi 


\section{The future of pensions in Europe}

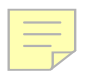

\section{Michele Boldrin, Juan J. Dolado, Juan F. Jimeno and Franco Peracchi}

Universidad Carlos III de Madrid, University of Minnesota and CEPR; Universidad Carlos III de Madrid and CEPR; Universidad Alcalà de Henares, FEDEA and CEPR; Università di Roma Tor Vergata

\section{INTRODUCTION}

In this paper we challenge the received wisdom that the ageing bomb will, and should, explode our unfunded pay as you go (PAYG) public pension systems; and that a rapid transition to fully funded, or capitalized, pension plans is the best solution. This recommendation is misguided and unwise. We dispute both the assumptions and the analysis on which they are based.

For a detailed articulation of the consensus view, see World Bank (1994), BIS (1998) and the literature quoted therein. Here we offer a simplified summary of this view. Because of demographic trends, during the next 30 to 50 years, the elderly dependency ratio (ratio of population older than 60 to the population aged 20 59) will keep growing, probably to double its current high level. Under the pension systems prevailing in the $\mathrm{EU}$, this implies continuous growth of the pension burden, the ratio of total pension to GDP.

Pensions, already $12 \%$ of EU GDP in 1995, are being financed almost entirely by a tax on labour income. Reasonable projections put the pension burden well above $20 \%$ of GDP within a few decades. The Stability and Growth Pact, limiting the size of deficit/GDP ratios, will force EU countries to raise taxes to finance the increasing pension outlays. This will raise labour costs dramatically, reduce employment, and generate social and political unrest. Maintaining a PAYG pension system also reduces

We thank the editors, two anonymous referees, Friedrich Breyer, Karl Moene, Samuel Bentolila and the participants at the $29^{\text {th }}$ Economic Policy Panel meeting for helpful comments on the first draft of this paper. 
current savings, damaging the growth of income and employment and increasing the size of the social security tax paid by the working few.

Various reform proposals have been advanced; see again World Bank (1994) and BIS (1998) but also Davis (1998), Diamond (1997), European Commission (1997), Feldstein (1996), Feldstein and Samwick (1998), Holzmann (1997), Kotlikoff (1995, 1996) and Mitchell and Zeldes (1996). A common feature of these proposals is that, starting with the second decade of the next millennium, old age pensions should be financed not, as today, by a tax on earnings, but instead by annuities generated by financial assets that are titles to the existing stock of productive capital.

The intuition behind this recommendation is straightforward. Total earnings, upon which taxes are levied to finance pension payments, have been growing slowly during the last two decades (2\% a year in the EU, since the mid 1970s) and are likely to grow at a similar pace in the foreseeable future. In contrast, the growth rate of the market value of private investments, as measured by the growth rate of stock market indexes, has been much higher $(10 \%$ a year in real terms in the EU, since the early 1980 s) and is not expected to drop in the future. Consequently, working people are putting their retirement eggs in the wrong basket. Barring an unlikely dramatic increase in future contribution rates, the rate of return they will earn on their own pension contributions may be less than a quarter of what they could have earned by investing in an appropriate mixture of stocks and bonds.

According to its proponents, reallocating resources from PAYG contributions to financial assets would eliminate many shortcomings of current systems. First, demographic oscillations would no longer affect the financial viability of pension payments. Second, political meddling with retirement income would be eliminated. Third, private saving and investment would be boosted, fostering economic growth. Feldstein (1995) provides a list of conditions under which a shift from unfunded to funded systems should raise social welfare: (1) a positive growth rate of the economy; (2) a rate of return on capital higher than the growth rate of national income; and (3) a rate of return on capital higher than the rate of time preference. Abundant statistical evidence shows that conditions (1) and (2) are easily satisfied in the EU countries. The large flows of private saving towards financial markets in the last two decades suggest that (3) is also true.

We claim that this 'consensus view' is seriously incomplete in its diagnosis of the deficiencies of PAYG systems, biased in its description of the merits of the fully funded ones, and off the mark in identifying the structural factors making unfunded systems financially unsustainable. We aim to expose the flaws in the 'consensus view', then to provide a more complete analytical framework for thinking about social security reforms in Europe.

The benefits of a shift to a fully funded system are said to be derived from four statements, put forward either as undisputed facts or as obvious assumptions:

(a) The projected dramatic increase in the pension burden is mainly due to a demographic shock, which can be avoided only by abandoning PAYG systems. 
(b) Transition to a fully funded system can be engineered without a large fall in the pension payments of the currently retired and of cohorts due to retire during the next 30 years.

(c) The rate of return on capital will always exceed the growth rate of total earnings.

(d) An efficient pension system should be a mix, primarily based on a capitalization scheme.

We claim these assumptions or assertions should be replaced with the following:

(A) A quarter of the projected increase in the pension burden reflects demographic change; three quarters reflects worsening labour market conditions and growing pension generosity.

(B) Transition to a fully funded system cannot be achieved without a substantial reduction in current pension payments unless it is financed by issuing public debt. The gains from such transition would accrue to generations that are not yet born.

(C) It is likely that the growth rate of earnings will continue to be smaller, on average, than the rate of return on capital, but the latter is much more volatile. Historically, the two returns are negatively correlated.

(D) An efficient pension system should be a mix of funded and PAYG systems. The mix should evolve with the movements in returns on physical and human capital and their correlation.

We contrast the two sets of claims (a) (d) and (A) (D). Section 2 describes current systems of social protection and pensions, and reports demographic and labour market projections up to 2050. At first sight, current EU systems of contributory public pensions are financially doomed. In addition to demography, two other trends play a key role: much lower labour force participation and much higher unemployment rates; and the practice of increasing real pensions, even after retirement, at the rate of labour productivity growth. Simulations in section 3 quantify these factors and show that claim (A) is a much better description of the facts than (a).

Section 4 supports claim (B) over (b). It draws on simple logical considerations (developed first in Breyer (1989) and extended by various authors) and on the few studies that try to quantify the implications of a transition from unfunded to fully funded systems (especially Holzmann, 1997; Miles, 1999; Miles and Iben, 1998; and Miles and Timmermann, 1999). Even if the growth rate of earnings is permanently lower than the rate of return on capital, once a PAYG system is in place it is not possible to shift to a capitalization system and make future generations better off without making at least one intermediate generation worse off. This has serious critical implications for those reform proposals, like that of Feldstein (1999), which advocate investing social security contributions in the stock market as an almost painless way of avoiding the future pension burden.

Quantitative exercises show that the benefits from a new funded system will accrue only to generations scarcely or not yet born; financing the transition imposes large costs 
on generations currently alive. No free lunches are available. Nor will taxing current generations (voters) to benefit future generations (not yet voters) be politically appealing. Policies to spread costs and benefits more smoothly across generations should therefore be designed.

The second half of section 4 considers claims (c) and (C), which are not mutually inconsistent. However, the attractiveness of different investment strategies cannot be established by looking only at expected returns. Risk matters and should affect reform design.

Section 5 shows why human capital is the first and most natural candidate for an asset in pension portfolios. We show how integrated public education and PAYG pension systems can be used to achieve the efficient level of investment in human capital. This simple insight shows that a pension system based upon capitalization alone cannot be efficient. Feldstein's (1995) claim for the superiority of funded systems is wrong not just because it neglects transitional costs, but also because it is dominated by a mixed PAYG

and fully funded system. Even if transition were costless, we would not want to implement a complete shift from PAYG to capitalization.

This link between pension risk and optimal portfolio allocation is not new (see Merton, 1983). What is new is the logical and practical connection we establish between public investment in education and payments of future retirement pensions. A logically correct and socially efficient approach to reforming pension systems takes public financing of education (not social security contributions) as the investment on which pensions are the due return. While the growth rate of earnings may be lower than the rate of return on physical capital, its riskiness is also much lower. Indeed, the negative correlation between the two returns suggests that a well diversified portfolio should contain both. Claim (D) is better than (d).

Thus, section 2 describes the current situation and likely trends in the absence of reform. Section 3 examines how the PAYG burden is affected by labour market conditions and the generosity of pensions. Section 4 shows that transition from PAYG to full funding cannot benefit every generation, and that benefits are likely to accrue only to generations not yet born. Section 5 proposes an analytical framework for thinking about the design of efficient pension systems. Section 6 elaborates implications for policy design.

\section{EUROPEAN PENSION SYSTEMS: FACTS AND THE CURRENT DEBATE}

First, we briefly describe the relevance of social protection expenditures (SPE), in which the role of pensions is prominent. Second, we document the demographic and labour market scenarios under which pension systems are expected to operate in future decades. Finally, we briefly describe the main institutional features of European pension systems.

\subsection{Social protection expenditures}

Social protection expenditure is a major part of public spending in all EU countries, although Table 1 shows important differences across countries. In 1995 overall SPE was 
$28 \%$ of GDP and $52 \%$ of total government expenditures in the EU. As a share of GDP, it is lowest in the southern countries and Ireland (around 20\%), and highest in the Nordic countries (around 35\%). SPE per capita also varies markedly between northern and southern EU countries, being double in the latter what it is in the former. This pattern is broadly in line with the levels of GDP per capita.

The last two columns of Table 1 report the ratio of pension expenditures to SPE and to GDP. Excluding Greece (data unavailable), EU pension expenditures in 1995 were to $42 \%$ of SPE and $12 \%$ of GDP. In all EU countries, except Ireland, pensions are the largest component of SPE, ranging from $32 \%$ in Finland to $63 \%$ in Italy.

\subsection{Demographic and labour market scenarios}

2.2.1. The demographic scenario. This section compares the current demographic structure of EU economies, taking into account the evolution of fertility rates and life expectancy over the period 1960 95. Demographic projections of the relevant dependency ratios for the period 19952050 are then presented.

Total population in the EU (including eastern German Lander) rose from 315 million in 1960 to 374 million in 1995 . This average annual growth of $0.45 \%$ fluctuated across decades, being as high as $0.8 \%$ in the $1960 \mathrm{~s}$, but only $0.25 \%$ in the $1980 \mathrm{~s}$. Despite a small recent recovery of population growth, mostly due to rising net migration and higher fertility rates in Scandinavia, demographers seem to agree that EU population growth will slow down.

Table 1. Social protection and pension spending in the EU, 1995

\begin{tabular}{lcccc}
\hline \hline & \multicolumn{2}{c}{ Social protection spending } & & \multicolumn{2}{c}{ Pension spending } \\
\cline { 2 - 5 } & \% of GDP & \% of & \% of SPE & \% of GDP \\
\cline { 3 - 5 } Austria & 30 & 55 & 47 & 14 \\
Belgium & 30 & 53 & 40 & 12 \\
Denmark & 34 & 55 & 37 & 13 \\
Finland & 34 & 55 & 32 & 10 \\
France & 31 & 55 & 41 & 13 \\
Germany & 30 & 54 & 41 & 12 \\
Greece & 21 & 45 & 25 & 5 \\
Ireland & 20 & 40 & 63 & 15 \\
Italy & 25 & 54 & 43 & 11 \\
Luxembourg & 25 & 58 & 36 & 11 \\
Netherlands & 32 & 56 & 39 & 8 \\
Portugal & 21 & 42 & 44 & 10 \\
Spain & 22 & 50 & 37 & 13 \\
Sweden & 36 & 49 & 38 & 10 \\
UK & 29 & 57 & 42 & 12 \\
EU average & 28 & 52 & & 5 \\
\hline \hline
\end{tabular}

Note: SPE is social protection expenditure, $\mathrm{G}$ is total government spending.

Source: Eurostat. 
Current trends in fertility are documented in Table 2. There has been a large decline in fertility rates, especially where these were initially highest (Ireland, the Netherlands, Portugal and Spain). Life expectancy rose considerably during 1960 95. Fertility has shown a negative relation between initial levels and subsequent evolution. The dispersion across EU countries in both fertility and life expectancy has decreased noticeably.

Table 3 provides a synthetic comparison of the current demographic structure of the EU countries, and the future evolution implied by Eurostat's baseline demographic projections (Eurostat, 1996). It shows the youth dependency ratio (ratio of people aged less than 20 to the working age population aged 20 59), and the old age dependency ratio (the ratio of people aged $60+$ to the working age population). Two groups of countries are evident, with two outliers, Ireland and Italy. Dependency is high in the first group (Belgium, France, Greece, Spain, Sweden and the UK) but low in the second group (Austria, Denmark, Germany and the Netherlands). Ireland has a high youth dependency ratio, but a relatively low old age ratio; Italy has a high old age dependency ratio and a relatively low youth dependency ratio.

In all countries, old age dependency ratios are expected to increase substantially, nearly doubling by 2050. Youth dependency ratios should fall slightly until 2020, then come back somewhat. For old age ratios, Belgium, Finland and Italy are expected to have the largest in 2020, while Spain, Italy and Ireland face the most severe old age demographic pressure in 2050, with ratios above $80 \%$ of the working age population. Changes in the youth ratios are much smaller, with the exception of Ireland, where the

Table 2. Demographic indicators in the EU, 1995

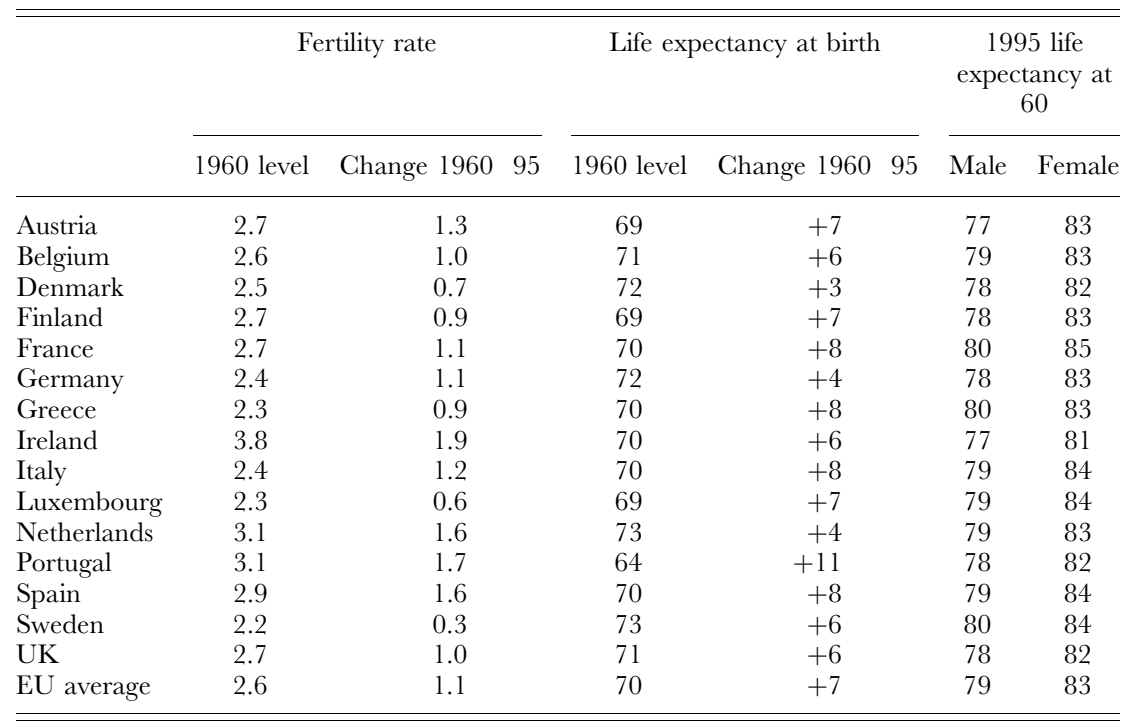

Source: Eurostat. 
Table 3. EU dependency ratios: actual and projections to $2050(\%)$

\begin{tabular}{|c|c|c|c|c|c|c|c|c|c|}
\hline & \multicolumn{3}{|c|}{ Youth (under 19) } & \multicolumn{3}{|c|}{ Elderly (60 and over) } & \multicolumn{3}{|c|}{ Total } \\
\hline & 1995 & 2020 & 2050 & 1995 & 2020 & 2050 & 1995 & 2020 & 2050 \\
\hline Austria & 41 & 37 & 40 & 35 & 46 & 67 & 76 & 83 & 107 \\
\hline Belgium & 44 & 42 & 44 & 39 & 54 & 66 & 83 & 96 & 111 \\
\hline Denmark & 42 & 44 & 44 & 35 & 49 & 58 & 77 & 91 & 101 \\
\hline Finland & 46 & 44 & 44 & 34 & 57 & 65 & 80 & 101 & 109 \\
\hline France & 49 & 44 & 45 & 37 & 53 & 71 & 86 & 97 & 116 \\
\hline Germany & 37 & 35 & 38 & 36 & 52 & 64 & 73 & 87 & 102 \\
\hline Greece & 45 & 42 & 43 & 40 & 52 & 71 & 85 & 94 & 114 \\
\hline Ireland & 67 & 49 & 48 & 30 & 50 & 105 & 97 & 99 & 152 \\
\hline Italy & 38 & 36 & 38 & 40 & 56 & 82 & 78 & 92 & 119 \\
\hline Luxembourg & 42 & 42 & 44 & 34 & 47 & 58 & 75 & 88 & 102 \\
\hline Netherlands & 42 & 42 & 44 & 31 & 50 & 62 & 73 & 91 & 106 \\
\hline Portugal & 48 & 42 & 43 & 37 & 45 & 66 & 85 & 86 & 108 \\
\hline Spain & 46 & 37 & 46 & 38 & 48 & 83 & 84 & 86 & 121 \\
\hline Sweden & 46 & 45 & 43 & 41 & 53 & 59 & 88 & 98 & 105 \\
\hline UK & 47 & 41 & 43 & 38 & 48 & 67 & 85 & 90 & 110 \\
\hline EU average & 43 & 39 & 41 & 37 & 51 & 72 & 80 & 91 & 113 \\
\hline
\end{tabular}

Source: Eurostat.

dependency ratio is expected to fall by almost 20 percentage points between 1995 and 2020, and then remain low.

2.2.2. The labour market. Tables 4 and 5 show falling labour force participation rates (LFPRs) for youths, but rising unemployment rates for all age groups, resulting in shorter contribution periods to the pension systems. LFPRs among the elderly have fallen substantially, particularly among men, shortening contribution periods and increasing the demand for pensions. Further, the incidence of unemployment among the elderly is much higher nowadays, increasing pressure on pensions to substitute for unemployment benefits in providing income for elderly unemployed workers.

Table 4 reveals marked differences across countries. Southern Europe has low youth LFPRs, whereas Nordic countries have high LFPRs among the elderly. For central age groups, the main differences arise from the behaviour of women, whose LFPRs are lowest in the southern countries. The gap between male and female LFPRs is relatively small in Scandinavian countries, particularly for ages over 45, but still sizeable in Belgium, Ireland and southern Mediterranean countries. Figure 1 shows the probability that a worker of a given age in the range 4569 will retire within one year. That probability is the slope of the current age participation profile. Peaks at particular ages (typically 60 or 65) relate to rules governing retirement in the various countries and, in particular, to the presence of early and normal retirement ages. This effect is strong in France, Germany, Spain, Sweden and the UK. Unemployment rates in Table 5 do not need much comment: the incidence of unemployment has increased across the board. 
Table 4. Participation rates by age and sex, 1980 and 1995

\begin{tabular}{|c|c|c|c|c|c|c|c|c|c|c|c|c|}
\hline & \multicolumn{4}{|c|}{ Age $15 \quad 24$} & \multicolumn{4}{|c|}{ Age $25 \quad 54$} & \multicolumn{4}{|c|}{ Age $55 \quad 64$} \\
\hline & \multicolumn{2}{|c|}{ Men } & \multicolumn{2}{|c|}{ Women } & \multicolumn{2}{|c|}{ Men } & \multicolumn{2}{|l|}{ Women } & \multicolumn{2}{|c|}{ Men } & \multicolumn{2}{|c|}{ Women } \\
\hline & 1980 & 1995 & 1980 & 1995 & 1980 & 1995 & 1980 & 1995 & 1980 & 1995 & 1980 & 1995 \\
\hline Austria & n.a. & 65 & n.a. & 59 & n.a. & 93 & n.a. & 73 & n.a. & 43 & n.a. & 19 \\
\hline Belgium & 46 & 36 & 42 & 32 & 94 & 92 & 54 & 6 & 51 & 36 & 12 & 13 \\
\hline Denmark & 68 & 77 & 62 & 69 & 94 & 92 & 84 & 82 & 67 & 68 & 42 & 40 \\
\hline Finland & 64 & 51 & 53 & 39 & 92 & 88 & 81 & 85 & 56 & 42 & 41 & 42 \\
\hline France & 53 & 33 & 44 & 27 & 96 & 95 & 63 & 77 & 70 & 42 & 39 & 31 \\
\hline Germany & 63 & 57 & 57 & 50 & 95 & 93 & 55 & 73 & 67 & 54 & 28 & 31 \\
\hline Greece & 50 & 41 & 36 & 33 & 95 & 95 & 44 & 55 & 71 & 61 & 26 & 25 \\
\hline Ireland & 69 & 49 & 54 & 42 & 95 & 91 & 28 & 55 & 78 & 64 & 20 & 21 \\
\hline Italy & 49 & 44 & 40 & 34 & 93 & 89 & 39 & 54 & 56 & 44 & 11 & 14 \\
\hline Luxembourg & 63 & 43 & 58 & 40 & 95 & 94 & 41 & 53 & 38 & 35 & 15 & 13 \\
\hline Netherlands & 49 & 62 & 46 & 62 & 93 & 93 & 34 & 66 & 65 & 41 & 14 & 19 \\
\hline Portugal & 78 & 47 & 64 & 39 & 95 & 94 & 55 & 74 & 76 & 62 & 32 & 35 \\
\hline Spain & 71 & 48 & 49 & 42 & 96 & 93 & 30 & 55 & 77 & 55 & 22 & 20 \\
\hline Sweden & 72 & 50 & 70 & 50 & 95 & 91 & 81 & 86 & 79 & 70 & 55 & 63 \\
\hline UK & 87 & 74 & 68 & 65 & 95 & 93 & 69 & 74 & 79 & 62 & 38 & 41 \\
\hline EU average & 63 & 52 & 53 & 44 & 94 & 92 & 54 & 69 & 65 & 52 & 28 & 28 \\
\hline
\end{tabular}

Source: OECD, Employment Outlook, various issues.

Table 5. Unemployment rates by age and sex, 1980 and 1995

\begin{tabular}{|c|c|c|c|c|c|c|c|c|c|c|c|c|}
\hline & \multicolumn{4}{|c|}{ Age $15 \quad 24$} & \multicolumn{4}{|c|}{ Age $25 \quad 54$} & \multicolumn{4}{|c|}{ Age $55 \quad 64$} \\
\hline & \multicolumn{2}{|c|}{ Men } & \multicolumn{2}{|c|}{ Women } & \multicolumn{2}{|c|}{ Men } & \multicolumn{2}{|c|}{ Women } & \multicolumn{2}{|c|}{ Men } & \multicolumn{2}{|c|}{ Women } \\
\hline & 1980 & 1995 & 1980 & 1995 & 1980 & 1995 & 1980 & 1995 & 1980 & 1995 & 1980 & 1995 \\
\hline Austria & n.a. & 6 & n.a. & 6 & n.a. & 4 & n.a. & 5 & n.a. & 4 & n.a. & 3 \\
\hline Belgium & 10 & 20 & 29 & 24 & 7 & 6 & 15 & 11 & 12 & 4 & 4 & 4 \\
\hline Denmark & 18 & 8 & 19 & 12 & 7 & 5 & 8 & 8 & 6 & 7 & 7 & 10 \\
\hline Finland & 11 & 41 & 11 & 28 & 5 & 15 & 4 & 15 & 4 & 16 & 6 & 23 \\
\hline France & 9 & 21 & 19 & 32 & 3 & 9 & 6 & 13 & 4 & 8 & 5 & 7 \\
\hline Germany & 3 & 8 & 5 & 8 & 2 & 6 & 4 & 9 & 6 & 11 & 6 & 14 \\
\hline Greece & 17 & 19 & 30 & 38 & 5 & 5 & 8 & 11 & 3 & 4 & 2 & 3 \\
\hline Ireland & 10 & 21 & 8 & 17 & 7 & 11 & 5 & 11 & 7 & 8 & 4 & 9 \\
\hline Italy & 21 & 29 & 31 & 38 & 2 & 7 & 7 & 12 & 2 & 4 & 7 & 5 \\
\hline Luxembourg & 5 & 7 & 8 & 8 & 2 & 2 & 4 & 4 & 0 & 0 & 4 & 1 \\
\hline Netherlands & 7 & 12 & 9 & 13 & 3 & 5 & 3 & 8 & 3 & 4 & 3 & 3 \\
\hline Portugal & 10 & 15 & 27 & 17 & 2 & 5 & 7 & 7 & 0 & 5 & 1 & 3 \\
\hline Spain & 18 & 37 & 22 & 49 & 6 & 15 & 5 & 28 & 5 & 13 & 1 & 11 \\
\hline Sweden & 5 & 17 & 5 & 14 & 1 & 7 & 2 & 6 & 2 & 9 & 2 & 6 \\
\hline UK & 9 & 18 & 8 & 12 & 5 & 9 & 6 & 6 & 8 & 10 & 5 & 4 \\
\hline EU average & 11 & 19 & 17 & 22 & 4 & 8 & 6 & 11 & 4 & 9 & 4 & 8 \\
\hline
\end{tabular}

Source: OECD, Employment Outlook, various issues. 


\subsection{Early retirement and youth unemployment: any relationship?}

Employment rates of elderly workers are falling, largely as a result of deliberate government policies. This is the single most damaging factor for financial sustainability of PAYG pension schemes. As an important source of differential treatment for similar workers, it has been a tool for political rent seeking and vote buying. Policies favouring early retirement are often justified as a way to reduce youth unemployment. This requires that there are a fixed number of total jobs, so that retiring an older worker 'frees' the same job for a younger one.

We collected labour market data for 260 NUTS II and NUTS III European regions in 1986, 1991 and 1996. These small areas are the territorial units at which the European Commission targets employment policies and for which national governments devise early retirement plans. Figures 2 and 3 plot, for men and women, the relationship between the exit rates from the labour force of people born during 193140 and changes in unemployment rates over 19916 of people aged 21 30. The substitution hypothesis would imply a negative relationship. Our estimates find no such significant relationship either for men or for women. Controlling for cohort effects or using different lags hardly changes these results. Early retirement of older workers does not induce lower youth unemployment.
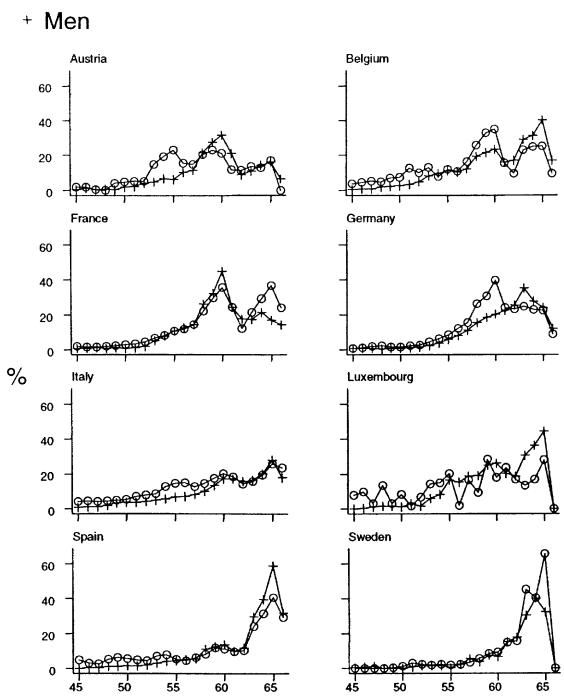

- Women
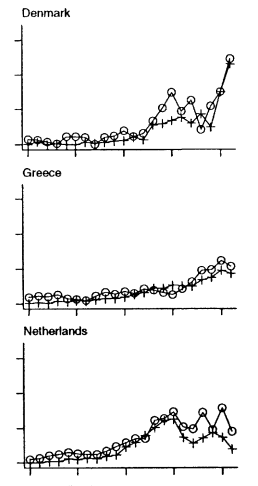

United Kingdom

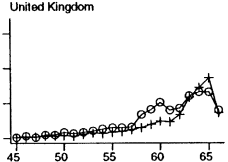

Age
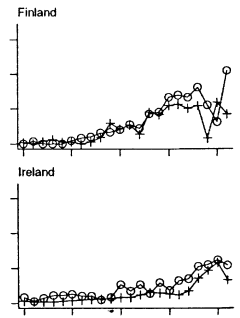

Portugal

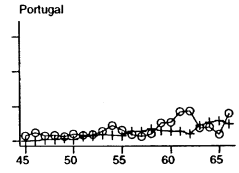

Figure 1. Exit rates from the labour force, average 19946 


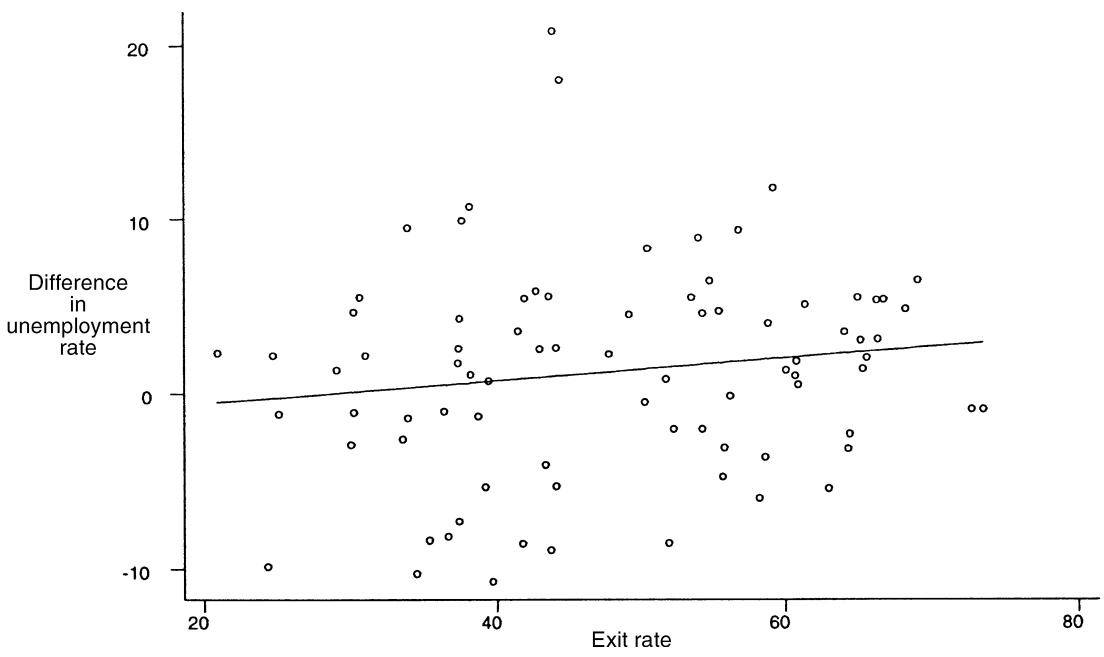

Figure 2. Exit rates of men born 193140 , and changes in unemployment rates of men aged 2130,19916

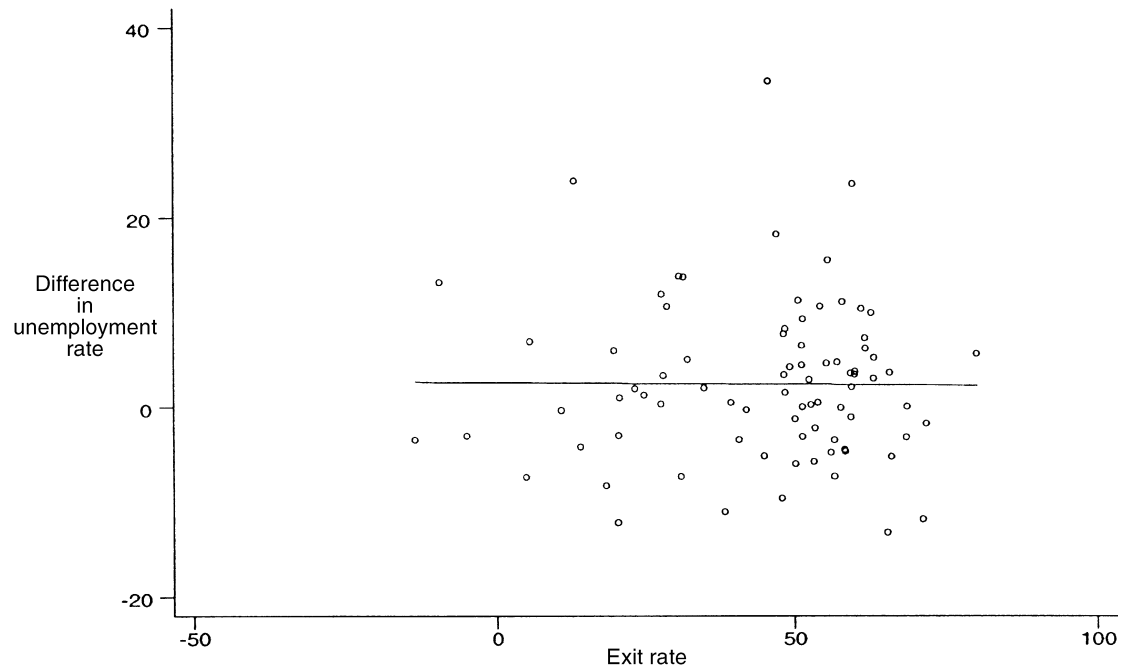

Figure 3. Exit rates of women born 193140 , and changes in unemployment rates of women aged 2130,19916 


\subsection{The institutional framework}

Pension schemes are mainly PAYG systems or funded systems, and may cover all citizens, whether in need or not, or only contributors to a social insurance scheme. Contributions and benefits may be flat rate (Beveridge formula), earnings related (Bismarck formula) or, as in Scandinavian countries, of both types. In addition, many EU countries have supplementary schemes, voluntary or compulsory, funded or unfunded, often organized on an occupational, employment related base. Obviously, retirement income may also be provided through private pension funds, which are regulated and taxed differently in each country. Except for the UK, the Netherlands and Scandinavia, private pension funds still provide a very low fraction of total retirement income. Table Al in the appendix provides a brief summary.

The interaction among the layers of different pensions systems makes it hard to characterize their structure. Table A2 in the appendix summarizes the main rules of earnings related plans. ${ }^{1}$ Public earnings related pensions are usually mandatory and cover most employees: benefits are financed by contributions of employees and employers. These systems are characterized by the contribution rate, the minimum contribution period to qualify for benefits, the standard age of entitlement (which, with life expectancy, determines the duration of benefits), the replacement rate (the ratio of initial pension benefits to final earnings), the indexation rules and the amount of benefits going to survivors.

The parameters in Table A2 can be used to compute, for each plan, the internal rate of return (IRR) and the ratio between average pension $p$ and labour productivity $y$, given age, work seniority and earnings profiles. The IRR is the discount rate that makes the present discounted value of the flow of pension benefits equal to the present discounted value of the flow of social security contributions. When compared to the growth rate of the total wage bill, the IRR indicates the long run solvency of a pension plan. For a given contribution rate, if the average IRR is greater than the growth rate of total labour income, additional resources are needed to finance pensions (Samuelson, 1975). The ratio of average pension and labour productivity, together with the elderly dependency ratio, determines the ratio of pension expenditures to GDP and therefore drives the overall financial sustainability of the system.

Table 6 estimates IRRs and the ratio of pension to average productivity for some EU countries. We make the following simplifying assumptions. Contribution rates remain constant at current levels (Table A2). The contribution period is 35 years (often above the average working period implied by the employment rates in Tables 4 and 5). The retirement period is current life expectancy at 60 years (Table 2). Pension benefits obey current rules, usually relating the pension replacement rate to the length of the contributory period and the worker's average earnings during a given period (Tables A2 and 6). Pensions are determined by the replacement ratio plus the ongoing indexation rule

${ }^{1}$ For a detailed discussion of institutional features, see European Commission (1997) and the literature quoted therein. 
Table 6. Internal rates of return and pension benefits

\begin{tabular}{|c|c|c|c|c|}
\hline & $\begin{array}{l}\text { Years } \\
\text { retired }\end{array}$ & Benefits & $\begin{array}{r}\text { IRR } \\
(\%)\end{array}$ & $\begin{array}{l}\text { Pension as \% } \\
\text { of productivity }\end{array}$ \\
\hline Austria & 21 & $\begin{array}{r}1.9 \% \text { of wage for each year } 1 \quad 15 \\
+1.5 \% \text { of wage for each year } 16 \quad 34\end{array}$ & 3.0 & 43 \\
\hline Belgium & 21 & $0.675(35 / 42.5)$ times lifetime average wages & 3.8 & 32 \\
\hline Finland & 20 & $\begin{array}{l}0.575 \text { times average wage in } 2 \text { of last } 4 \text { years } \\
\text { (excluding highest and lowest wage) }\end{array}$ & 3.0 & 41 \\
\hline France & 22 & $0.5(35 / 37.5)$ times average wage in last 15 years & 3.3 & 31 \\
\hline Germany & 20 & $0.7(35 / 37.5)$ times lifetime average wage & 2.0 & 39 \\
\hline Greece & 21 & 0.5 times average wage in last 5 years & 2.7 & 36 \\
\hline Italy & 21 & 0.7 times lifetime average wage & 2.0 & 37 \\
\hline Portugal & 20 & 0.7 times average wage in last 10 years & 3.2 & 49 \\
\hline Spain & 22 & Average wage in last 15 years & 3.0 & 66 \\
\hline Sweden & 22 & 0.6 times lifetime average wage & 4.9 & 35 \\
\hline
\end{tabular}
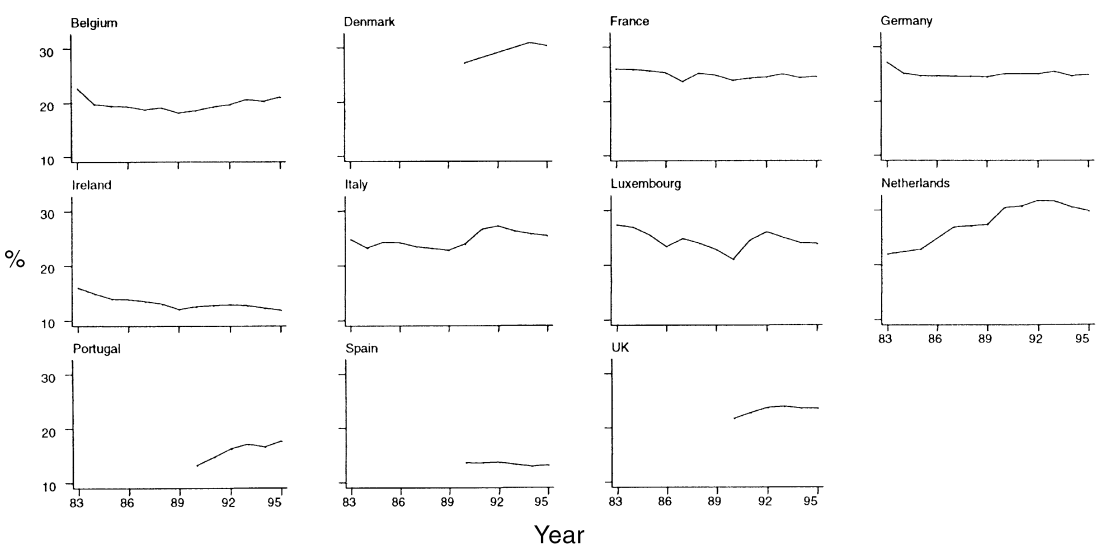

Figure 4. Average pension/labour productivity, 198395

(Table A2). Real wages grow at the same rate as labour productivity, during both the contributory and retirement periods, at an annual rate of $1.5 \%$ (Roseveare et al., 1996).

Our estimated IRRs, based on current rules, range from $2 \%$ in Germany and Italy to $5 \%$ in Sweden (where the contribution rate for the earnings related scheme is low). With future productivity and employment growing at 1.5 and $0.5 \%{ }^{2}$ respectively, the growth of the wage bill would be below our estimated IRRs (except maybe in Italy). Either extra resources are needed to cover pension expenditures or contributions must be raised and/or pension benefits lowered to avoid permanent deficits in the current pension systems.

${ }^{2}$ Even $0.5 \%$ employment growth is optimistic for the EU15 in the near future. 
For ratios of average pension to average labour productivity, our estimates range from $30 \%$ in France to $65 \%$ in Spain (whose $100 \%$ replacement rate of the average wage in the last 15 years of the working life is much the largest in our sample of countries). These estimates are not far from those currently observed in EU countries (except Spain and Portugal), as can be seen in Figure 4. Thus, if current rules are maintained, the only reason why the ratio of pension expenditures to GDP will increase is higher dependency ratios.

\subsection{The future of current systems: a simulation}

We now quantify the financial distress that European public pension systems are expected to suffer over the next 50 years. We simulate how the pension burden, the ratio between total pension expenditures and GDP, would evolve if current trends and legislation were maintained. Our simulations use the following decomposition of the pension burden:

\section{Pension expenditure GDP \\ Dependency rate \\ Labour force participation rate \\ $\times$ Employment rate \\ Pension per pensioner \\ GDP/worker}

Our baseline simulation supplements Eurostat demographic projections for 19952050 with two further assumptions: that age specific LFPRs and unemployment rates for both men and women remain constant at current levels; and that average labour productivity and average pension expenditure per pensioner grow annually by $1 \%$, keeping their ratio
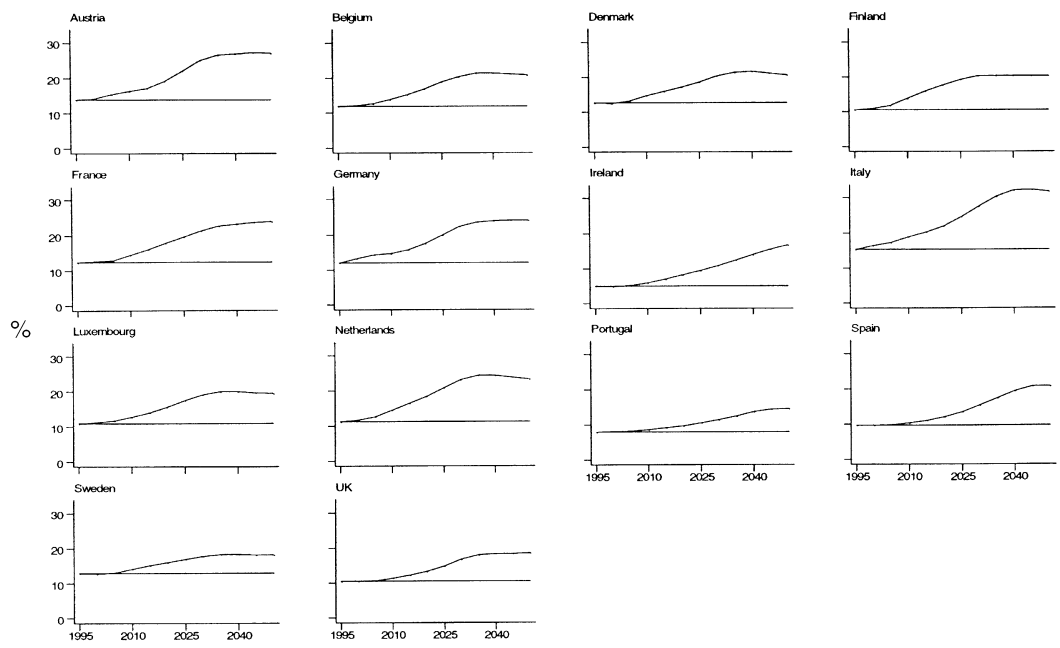

taly

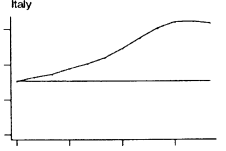

Portugal
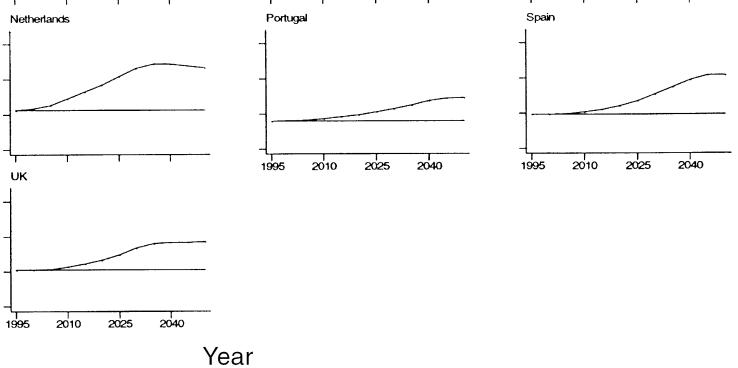

Figure 5. Pension expenditure/GDP by country: baseline simulation 
constant. This last assumption is not far from the observed evidence during the period 198395 which, for most EU countries, shows no clear trend in that ratio (Figure 4).

This simulation shows pure demographic effects, with no changes in participation rates, unemployment rates, or the ratio of pensions per pensioner to labour productivity. The results are presented in Figure 5, which also reports the 1995 pension burden for comparison.

The simulated pension burden grows in all countries, especially in France, Germany, Italy, the Netherlands and Spain. The increase is most notable in Italy, where a peak of $32.4 \%$ is reached in 2045. In France the peak of $24 \%$ is reached in 2050, in the Netherlands $24.2 \%$ is reached in 2035, in Germany $24.1 \%$ is reached in 2045, in the UK $18.5 \%$ is reached in 2050, and in Spain $21 \%$ is reached in 2050. These are very high numbers, more than twice the current values, and lend additional support to the view that PAYG pension systems are doomed and that financial collapse can be averted only by a swift transition to a funded system.

\section{QUANTIFYING THE SOURCES OF LONG-RUN IMBALANCE}

Unlike demographic trends, which are hard to affect by policy, participation rates, unemployment levels and labour productivity are sensitive to changes in fiscal policies and labour market legislation. Recent empirical evidence, such as Blöndal and Scarpetta (1998) and Gruber and Wise (1998), also shows that several provisions of current PAYG systems tend to lower labour force participation, facilitate early retirement and reduce labour supply by citizens older than 50. Such provisions are not inevitable features of PAYG systems, but rather the result of the political pressure and rent seeking behaviour of special interest groups.

This is crucial for understanding the significance of the simulations that follow. They are not meant to suggest that changing labour market behaviour to affect the solvency of PAYG schemes is an easy task. Instead, we wish to demonstrate that it is not the PAYG nature of the system that is leading to its financial collapse, and that the demographic crisis, while serious, could be overcome if these other factors were not present.

After 1973 European productivity growth slowed and unemployment increased. Reversals of these trends could have a significant effect on the solvency of PAYG pension schemes. Further increases in labour force participation could also help. Moreover, the degree of generosity of the scheme could be altered as a political choice. Figure 4 showed that, in most EU countries, outstanding pensions have grown at roughly the same rate as average labour productivity for the last 1520 years: even after retirement, pensioners benefit from productivity increases. This is a generous policy in comparison with merely indexing pensions against inflation. If the replacement rate (the ratio of initial pension to final earnings) were kept constant, only new pensions would grow at the same rate as labour productivity. Let us call this a policy of constant generosity, with a lower case 'g'. European countries have instead adopted a policy of constant Generosity, with an upper case ' $\mathrm{G}$ ', with all pensions growing at the rate of labour productivity. This second kind of generosity is 
not an inevitable outcome of a properly functioning PAYG system, but rather the outcome of political pressure from elderly citizens. It is particularly destabilizing when coupled with increases in life expectancy of the size experienced by the EU countries during the last $30 \quad 40$ years.

Before deciding what is causing what, and what needs to be fixed, it is useful to separate the impact of one policy choice from another. Given the current rules of the system and current demographic trends, what would happen if female LFPRs converged to those already observed in the UK and Scandinavia? What would happen if, in addition, male employment rates were pushed back to the level of the early 1980s? What would happen if we moved from a policy of 'constant Generosity' to one of 'constant generosity'? Finally, what would happen if these changes in policy and labour market conditions all happened together?

\subsection{Alternative scenarios}

Our four simulations share the demographic trends and old age dependency ratios of the baseline simulation of section 2.5. Simulation 1 gradually increases labour force participation rates and reduces unemployment rates, completing the adjustment by 2050. Within this scenario, we distinguish two cases. In simulation la, age specific male LFPRs stay constant at their current level, female LFPRs increase until reaching $80 \%$ of those of men, whereas age specific male and female unemployment rates converge to a common value, equal to half the current level of male unemployment rates. In simulation $1 \mathrm{~b}$, age specific male LFPRs and unemployment rates revert to their levels in the early 1980s, female LFPRs increase until reaching $80 \%$ of those of men, and female unemployment rates converge to male rates.

Simulation 2 replaces 'constant Generosity' with 'constant generosity', while labour productivity grows annually at either $1 \%$ (simulation 2a) or $2 \%$ (simulation $2 \mathrm{~b}$ ). Everything else follows the same trends as in the baseline case. Simulation 3 combines simulations 1 and 2. Labour productivity grows at 2\% per year and we distinguish between the two alternative labour market scenarios (simulations $3 \mathrm{a}$ and $3 \mathrm{~b}$ ). Simulation 4 considers a policy of decreasing generosity, with the ratio between new pensions and labour productivity decreasing by half a percentage point a year, while labour productivity grows at $2 \%$ per year. We distinguish between the two alternative labour market scenarios (simulations $4 \mathrm{a}$ and $4 \mathrm{~b}$ ). Everything else follows the same trends as in the baseline case.

Our assumptions about the behaviour of the female labour force are not very demanding. Denmark, France, Germany and the UK have already reached female LFPRs near $80 \%$ of male rates. Other countries, such as Ireland, already show no gender differences in unemployment rates. Halving unemployment rates by 2020 is a tougher assumption whose realization would entail substantial changes in the functioning of the European markets. 


\subsection{Basic findings}

Figure 6 reports results of each of the eight simulations described above. For simplicity, we only report EU averages obtained by weighting the available countries (Austria, Finland, Greece and Sweden are excluded) by their share of the GDP. Each panel refers to one of the four basic simulations, and presents the ratio of pension expenditures to GDP, along with its current value (the unmarked horizontal line) and its value in the baseline case. We define the 'demographic burden' as the difference between the current pension expenditures/GDP ratio and its value in the peak year. We will be mainly concerned with the reductions in the demographic burden under each of the alternative scenarios.

In simulation 1, in which LFPRs increase and unemployment rates fall, the demographic burden is lower than in the baseline scenario by between one quarter (if only female LFPRs increase) and one third (if LFPRs increase for both men and women). These are substantial improvements over the baseline case. Such changes in labour market conditions would substantially alleviate the future fiscal burden of PAYG pension systems.

Higher participation rates are only a temporary palliative, since they eventually increase the number of pensions to be financed. However, the quantitative significance of this argument may be limited. To the extent that LFPRs increase among those already entitled to some minimum pension, the solvency of the system may be enhanced. This would apply in countries in which very short work histories currently bring generous pension entitlements (for quantitative evaluations, see the papers in Gruber and Wise (1998)). A similar argument applies to the possible effects of lower unemployment rates:

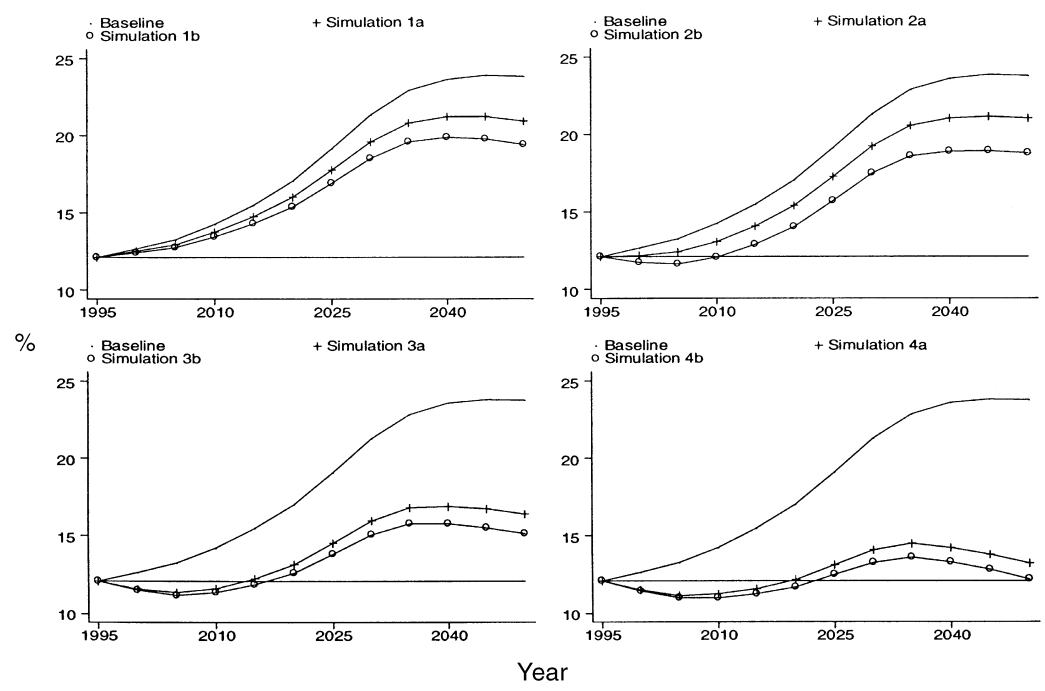

Figure 6. Pension expenditure/GDP: EU11 average 
all unemployment spells lasting less than two or three years do not reduce future pensions if 'figurative' contributions are being paid by the Social Security Administration. Even when there is a permanent increase in female labour market participation, the induced effect on pensions may be quite limited: non working women live longer than men, are typically married to working men, and would anyway have had a pension entitlement, even after the death of their husband. Getting those women to work and contribute is helpful. The peak burden is now lower than in the baseline case, and substantially lower for countries, such as Italy and Spain, where the current level of female LFPRs is low or male LFPRs have fallen very sharply during the last 15 years.

Simulation 2 replaces 'constant Generosity' with 'constant generosity', indexing pensions after retirement to prices but not to productivity and earnings growth. The typical profile of the demographic burden sees an initial small decline until about the year 2005, a subsequent increase until about the year 2035, and then a flattening or a mild decline. When the changes envisaged by the two previous scenarios are enacted simultaneously, the demographic burden in simulation 3 is reduced by at least half in all countries. Most countries actually generate a 'surplus' (relative to current expenditure levels) for the next 1015 years.

Simulation 4, which gradually cuts generosity, reduces the demographic burden by $3040 \%$, again generating large surpluses for the next decade or so. Moreover, simulations 1 and 4 together imply that most countries would be able to maintain their pension burden at or below its current (1995) level for the next 55 years. $^{3}$

These findings provide support for our first two policy prescriptions: before dismantling existing PAYG systems, there are important and reasonable policy options available to limit the fiscal burden caused by the ageing bomb. Of course, our simulations could be further refined. For example, they are 'partial equilibrium', treating productivity and wage growth as given, independently of postulated rises in female LFPRs and cuts in unemployment. Should higher effective labour supply induce lower real wages, pensions and the fiscal burden would fall, at least until all such effects had fully worked through the system, which would take several decades.

\section{RECONSIDERING THE TRANSITION TO A FULLY FUNDED SYSTEM}

EU governments should concentrate upon reducing unemployment and the growth rate of old pensions before starting to dismantle existing PAYG systems. Still, our discussion falls short of proving that a transition to a fully funded system would not be superior to even a reformed PAYG system. We now show why a PAYG system should continue to exist.

\footnotetext{
${ }^{3}$ Taking current pension burdens as a reference point, the 'surpluses' available in the next 15 years, if properly capitalized, could help finance subsequent deficits. Such a policy has been adopted in the USA. Current surpluses of the Social Security Administration are being kept, at least from an accounting point of view, in a Trust Fund to be used later to mitigate the impact of baby boomers' retirement.
} 
First, in a feasible transition to a fully funded system, all gains are accrued in the far future and all costs are paid up front. This makes the transition politically untenable unless intergenerational debt is issued to redress this balance. Second, an optimal portfolio should contain assets with payoffs determined by the return on both physical and human capital. Empirical evidence from the EU countries strongly supports this view, which is coherent with a stochastic version of the simple growth model that we outline in the following section.

In discussing the transition, we dispute the claim that a 'small tax now' plus the magic of financial markets is an easy and safe way to avoid the 'big tax later', the backbone of the proposal in Feldstein (1999) to reform the US social security system by introducing an additional $2.3 \%$ wage tax, whose proceeds would be invested in stocks and bonds. Assuming that the portfolio yields an average annual return of $5.5 \%$, the capitalized value of the tax flow would be enough to cover the additional pension payments that the US Social Security Administration is expected to face after 2030. Payroll social security contributions could then remain at the current level (12.4\%) instead of rising to $17.8 \%$ or higher, as is commonly forecast.

Would this reform help? Taxation would rise to $14.7 \%$, instead of staying at $12.4 \%$. What discount rate would equate the pain of an extra $2.3 \%$ in tax now and an extra $5.6 \%$ tax in 2030 ? The answer is $5.5 \%$. If this return can safely be earned in the financial markets, why not announce that the Payroll Social Security tax will remain at $12.4 \%$ for ever and that pension payments will have to balance the budget? Workers could then retain the $2.3 \%$ of their wages that otherwise would have gone in contributions, and be free to save and invest that money as their risk/return preferences suggest. This cannot be less efficient than an additional tax distortion plus a Federal official in charge of portfolio allocation. Miles and Timmermann (1999) also highlight the large increase in risk entailed in portfolio investment.

One should also consider the redistributive implications of any transition, which depend on whether fully funded systems replace the current PAYG systems or merely grow spontaneously in parallel to PAYG systems. We call the first approach 'replacement' and the second 'parallel'. To be effective, both approaches involve a sharp reduction in the pensions of those currently retired or going to retire in the next three decades, a serious issue of intergenerational redistribution, which needs to be addressed if even a partial transition to a fully funded system is to be viable.

Under the parallel approach, where will additional resources come from to be invested in funded pension plans? How will the saving rate be increased? 'Fiscal incentives' is a common refrain but not a realistic solution, not only because the Stability Pact restricts fiscal spending, but also because private saving is notoriously insensitive to tax incentives. Alternatively, the 'replacement' approach requires legal coercion to divert, towards saving and investment, resources currently taxed to finance pension payments. Will other resources be channelled to pensions or will per capita pensions gradually be reduced?

It is misleading to try to draw lessons from Chile or other Latin American countries, whose experience was shaped by elements completely missing in the EU. First, their 
unfunded pensions had been at relatively low levels. Second, it was politically feasible for them to implement a drastic reduction in the absolute income of pensioners. Third, their demographic structure was the opposite of the EU: many young and few old people.

Any transition to fuller funding is fundamentally an issue of intergenerational redistribution (see, e.g., Breyer, 1989). The point is simple and intuitive. If the currently old are expected to receive $p$ under the PAYG plan, switching to capitalization, without making the current generation worse off, implies financing inherited commitments by issuing an amount $p$ of public debt. From now on, working generations invest for their own retirement, but escape social security taxes previously used to fund the PAYG scheme. But somebody must bear the burden of the accumulated public debt. If this is charged to the new working generation, they are worse off. Since the argument presupposes that asset returns exceed productivity growth, the cost of repaying the debt with interest exceeds the social security contributions, even allowing for wage and productivity growth, that they would have had to pay under the old PAYG system. There is no free lunch.

Miles and Timmermann (1999) undertake quantitative simulations to estimate which generations gain and which lose. The answer is clear: under a wide range of realistic parameter values, a transition from unfunded to funded pensions would entail drastic cuts in living standards of generations currently alive, not only among existing pensioners, but even among the young who have yet to join the labour force. The generations that would gain have yet to be born. The redistributive implications make a full transition politically infeasible.

A (partial) transition to a fully funded system is realistic only if most of the transitional costs are financed by issuing new public debt, the cost of servicing and redeeming such debt then being shared equally by all the generations benefiting from the reform. Holzmann (1997) makes initial estimates of the amounts involved, but more empirical and theoretical work is needed before we can feel comfortable with this assessment. Such research is a priority because, in our view, this approach is probably the only way to implement any version of the 'consensus view'.

\section{DESIGNING AN OPTIMAL PENSION SYSTEM}

The supposed efficiency of a fully funded system is based upon the following two facts. First, PAYG pensions entail distortionary taxes to fund contributions, whereas funded pensions rely on voluntary private saving that involves no distortions. Second, unfunded systems are an income transfer from the young to the old. This is efficient only if the growth rate of the total wage bill is higher than the rate of return on capital (Diamond, 1977). When this is untrue, as in the EU during the last 20 years, PAYG pensions yield an inefficiently low return on money invested.

The first claim is correct and may be quantitatively important. It is less clear whether the response should be a switch to fully funded pensions or piecemeal reform of the PAYG system: for example, reducing generosity, to alleviate the distortionary burden of 
taxes that finance contributions. However, it would be wrong to view pension design merely through the lens of efficiency. In practice, pension funds reflect a host of fiscal and legal incentives unjustifiable on grounds of economic efficiency. This reveals that distributional and other implications of pension systems are of enormous importance, and we have explained why the distributional impact of a complete transition to full funding makes it a non starter.

The second claim is correct only in a world in which physical capital is the only reproducible production input and the only channel through which individuals can transfer income from the present to the future. It is not correct when there is a second productive asset, human capital, that can be accumulated over time, contributing to future production, but whose rights of ownership cannot be traded in financial markets or transferred from one individual to another. In such circumstances, efficient resource allocation over time requires accumulation of both productive assets in the appropriate proportion: namely, to the point at which, controlling for differential risks, the different investments yield the same return. Fully funded pension plans are not strictly superior to unfunded ones, either in theory or in fact. Neither strictly dominates the other. A well designed public pension system should adopt both.

\subsection{Why keep an unfunded pension system?}

Many problems of information and commitment inhibit the development of markets for credit to finance investment in individual human capital. Without well functioning credit markets, market forces do not bring about efficient resource allocation, either static or dynamic.

Suppose people live for three periods. The young attend school, receive an education and prepare for work. The middle aged sell their accumulated human capital on the market, earn a wage, consume and save for retirement. The old consume out of past savings. Each period, a new generation is born and an old one dies. Both human and physical capital are inputs to production. Better engineers operate machines more efficiently; more machines enhance the productivity of engineers. Ideally, both kinds of capital are accumulated. Assume the young have no resources to invest in their own education, and that parents choose privately to provide their children with a level of human capital that is too small for social efficiency: even when parents care about the consumption or the human capital level of their descendants, they do not fully internalize the benefits that this higher human capital conveys on the productivity of the descendants of other parents.

Suppose, first, that there is a complete set of financial markets. In particular, anyone can borrow at the going interest rate provided only that they are solvent and will credibly repay. To finance their education, the young borrow from the middle aged, who lend to the young, up to the point at which the return from this investment in future human capital equals the return on investment in physical capital. This stylized economy accumulates both types of capital in the efficient amounts. 
Incomplete markets, however, impair efficiency. In practice, many financial instruments exist to finance the accumulation of physical capital. It is mainly in the financing of human capital that market failures arise. Without government intervention, human capital would be well below the efficient level. How might this be remedied? Table 7 summarizes the tax/transfer process. Suppose members of subsequent generations implement a repeated sequence of intergenerational transfers. Each period, two taxes are levied on the middle aged to provide resources for two transfers. Revenue from the first tax is used to finance a pension for the elderly. Revenue from the second tax is used to finance investment in the education of the young.

\subsection{The optimal system of intergenerational transfers}

Complete markets would induce private behaviour that led to efficient amounts of educational investment and physical capital accumulation. With incomplete markets for the financing of human capital, in principle, one could choose the levels of taxation in the above scheme to ensure the same, efficient, level of human capital accumulation through education, the same investment in physical capital, and consequently the efficient level of pension in retirement. The middle aged can still be left to make private saving decisions and accumulate assets to finance their retirement.

In these circumstances, a PAYG scheme is efficient but a fully funded one is not. No matter how much the middle aged save to accumulate physical assets to provide for their retirement, this does nothing to help the young overcome market failures in borrowing to finance their education. Allowing explicit parental altruism might lead to partial funding, but, as we explained above, parents will never fully internalize the beneficial spillovers on children of other parents.

Nor could efficiency be accomplished by free public schooling unconnected to PAYG pensions. The induced wealth effects on the middle aged lead them to consume more than is dynamically efficient. Moreover, each middle aged generation would be tempted to dismantle public education when its turn to finance it arrived. Only the explicit intergenerational linkage (no pension for you if you default on financing the education of the young) underpins the correct allocation over time. ${ }^{4}$

Table 7. Generational income and spending, and lifetime budget

\begin{tabular}{lll}
\hline \hline Generation & Net incomings & Outgoings \\
\hline Young & Subsidy from first type of tax & Education \\
Middle aged & Labour income Two types of tax & Consumption + Saving \\
Old & Pension + Return on own savings & Consumption \\
\hline \hline
\end{tabular}

${ }^{4}$ For further discussion and technical details, see Boldrin and Montes (1998). 
Our scheme is also intergenerationally 'fair', providing each generation with a market driven return from its investment in human capital. In the literature on PAYG social security systems the issue of 'actuarial fairness' between contributions paid and pensions received is hotly debated. Our model suggests that one should test actuarial fairness by comparing contributions paid with the amount of public education received and by comparing taxes devoted to public education with pension payments.

Finally, we need to address the feasibility of such a scheme in the current EU context, and also recognize that the taxes we propose would themselves introduce further distortions. Political feasibility hinges on the extent to which the proposed system would affect the intergenerational transfers already taking place through public education and pensions. A proper answer requires extensive and detailed microeconomic data analysis country by country. Such study has been performed for Spain, ${ }^{5}$ where our scheme would imply only relatively minor adjustments relative to the current system. Taking current Spanish investment in public education as given, our estimate of the efficient system would entail lowering the average pension by $2 \%$.

\subsection{Risky returns revisited}

Our model treats returns on physical and human capital as safe; in practice, they are risky. Table 8 reports historical averages and Table 9 presents the estimated variance covariance matrix. We do not report explicit computations of private returns on human capital, for which we have been unable to find comparable estimates. To the extent that labour earnings are gross returns from human capital, their mean growth rate and standard deviations are a reasonable proxy for the corresponding return on human capital investment. The reported figures confirm that the return on physical capital is uncertain and risky, and that the rate of growth of real wages is less risky. Expected returns are higher for physical than human capital, but both their relative volatility and their covariance structure suggest that neither one dominates the other in a mean variance sense. More significantly, the two returns are negatively correlated. Diversification of risk provides an additional reason to invest in both human and physical capital, a second reason to retain some form of PAYG pension system.

Financial engineering alone would not suffice. Issuing bonds or derivative securities whose return is positively linked to the growth of labour earnings can help diversify individual portfolios, but it cannot diversify aggregate portfolios. The market portfolio can be diversified only if there are securities which finance investment in human capital and which, therefore, are direct claims to a portion of future labour earnings. A PAYG pension, in which returns are linked to previous investments in human capital, is just such a 'security'.

${ }^{5}$ See Boldrin and Montes (1998), and, for the complete details, Montes (1998). 
Table 8. Average real returns on different assets, 196196 (\% per annum)

\begin{tabular}{|c|c|c|c|c|c|c|c|c|}
\hline & & & USA & Germany & UK & France & Italy & Japan \\
\hline \multirow[t]{4}{*}{ GDP growth } & 1961 & 70 & 3.8 & 4.3 & 2.8 & 5.4 & 5.6 & 9.9 \\
\hline & 1971 & 80 & 2.8 & 2.7 & 1.9 & 3.3 & 3.5 & 4.4 \\
\hline & 1981 & 90 & 2.6 & 2.2 & 2.6 & 2.3 & 2.2 & 3.9 \\
\hline & 1991 & 96 & 2.1 & 3.2 & 1.5 & 1.2 & 1.0 & 1.8 \\
\hline \multirow[t]{4}{*}{ Earnings } & 1961 & 70 & 4.0 & 4.5 & 3.3 & 5.2 & 5.2 & 5.2 \\
\hline & 1971 & 80 & 2.6 & 3.0 & 1.9 & 3.9 & 3.6 & 3.6 \\
\hline & 1981 & 90 & 2.4 & 1.3 & 2.7 & 1.2 & 2.2 & 2.2 \\
\hline & 1991 & 96 & 2.1 & 3.2 & 0.6 & 0.8 & 0.3 & 0.3 \\
\hline \multirow[t]{4}{*}{ Long bonds } & 1961 & 70 & 1.7 & 3.0 & 2.8 & 2.1 & 2.2 & \\
\hline & 1971 & 80 & 0.1 & 2.7 & 1.6 & 0.4 & 3.4 & 0.5 \\
\hline & 1981 & 90 & 5.4 & 4.7 & 4.6 & 5.1 & 4.4 & 4.6 \\
\hline & 1991 & 96 & 4.3 & 4.0 & 4.8 & 5.6 & 6.5 & 3.7 \\
\hline \multirow[t]{4}{*}{ Equities } & 1961 & 70 & 4.8 & 4.1 & 0.3 & 3.4 & & 1.9 \\
\hline & 1971 & 80 & 0.2 & 4.3 & 4.5 & 4.4 & 17.9 & 4.9 \\
\hline & 1981 & 90 & 11.5 & 11.3 & 9.8 & 11.1 & 15.9 & 15.8 \\
\hline & 1991 & 96 & 16.5 & 0.3 & 5.4 & 0.1 & 4.5 & 4.4 \\
\hline
\end{tabular}

Notes: Earnings is real growth of employee compensation, adjusted for self-employment; return on long bonds is long-term interest rate deflated by growth of GDP deflator; real equity returns are growth rates of stock market indexes deflated by GDP (but, because of data unavailability, they do not include dividends).

Table 9. Standard deviations and correlations of annual returns, 196196

\begin{tabular}{|c|c|c|c|c|c|}
\hline & & GDP growth & Earnings & Bonds & Equities \\
\hline \multirow[t]{4}{*}{ USA } & GDP growth & 2.02 & & & \\
\hline & Earnings & 0.85 & 1.74 & & \\
\hline & Bonds & 0.01 & 0.02 & 2.48 & \\
\hline & Equities & 0.18 & 0.35 & 0.39 & 16.70 \\
\hline \multirow{4}{*}{ Germany } & GDP growth & 2.66 & & & \\
\hline & Earnings & 0.89 & 2.89 & & \\
\hline & Bonds & 0.10 & 0.31 & 1.45 & \\
\hline & Equities & 0.07 & 0.37 & 0.28 & 16.32 \\
\hline \multirow[t]{4}{*}{ UK } & GDP growth & 1.99 & & & \\
\hline & Earnings & 0.61 & 2.11 & & \\
\hline & Bonds & 0.35 & 0.09 & 3.51 & \\
\hline & Equities & 0.35 & 0.09 & 0.27 & 16.25 \\
\hline \multirow[t]{4}{*}{ France } & GDP growth & 1.96 & & & \\
\hline & Earnings & 0.80 & 2.19 & & \\
\hline & Bonds & 0.33 & 0.63 & 2.47 & \\
\hline & Equities & 0.11 & 0.39 & 0.21 & 18.73 \\
\hline \multirow[t]{4}{*}{ Italy } & GDP growth & 2.35 & & & \\
\hline & Earnings & 0.70 & 2.48 & & \\
\hline & Bonds & 0.27 & 0.39 & 4.41 & \\
\hline & Equities & 0.14 & 0.16 & 0.23 & 38.82 \\
\hline \multirow[t]{4}{*}{ Japan } & GDP growth & 3.53 & & & \\
\hline & Earnings & 0.69 & 2.48 & & \\
\hline & Bonds & 0.12 & 0.34 & 4.01 & \\
\hline & Equities & 0.20 & 0.08 & 0.29 & 19.08 \\
\hline
\end{tabular}

Notes: Standard deviations in bold. Data for Italian equities, and for bonds and equities in Japan, are for 197196 not 196196. 


\section{CONCLUSION AND POLICY RECOMMENDATIONS}

Public unfunded pension plans, currently in place in most European countries, are doomed to become fiscally, and therefore politically, untenable in about 15 to 25 years' time. This fate is determined by a number of concurrent factors: demographic trends, the rapidly increasing proportion of elderly people in the population; the rapid decrease in labour force participation of men, the slow increase in the participation of women, and persistently high unemployment rates; the policy of increasing the real value of outstanding pensions at the rate of labour productivity growth; and the policy of increasing incentives for early retirement by people aged 55 and over.

Only the first is truly exogenous difficult to modify by policy even in the medium run. All other trends reflect political choices. These may be based on legitimate social concerns, but are generally unrelated to the purposes and functioning of PAYG pensions.

Using calibrated numerical simulations, we have shown that, by reversing those ill fated political choices, unfunded public pension schemes could be rescued. Assuming labour productivity grows annually by $2 \%$ for the next 55 years, we can identify four conditions jointly sufficient to maintain the pension/GDP ratio below or equal to its current level until 2050. First, reduce the ratio between new pensions and labour productivity by half a percentage point a year, while maintaining the real value of old pensions. Second, during 200050 find a way to restore male labour force participation rates to the levels of the early 1980s. Third, raise female participation rates to $80 \%$ of male rates by 2050. Fourth, cut unemployment rates for men to half their current level, and equate female and male unemployment rates by 2050 .

Proponents of fiscally supported transitions to fully funded pensions have failed to consider or properly address several controversial issues. First, fiscal incentives to promote private pensions require higher taxation elsewhere. It is unclear where the additional saving comes from. Transition to a fully funded system requires either a drastic reduction in pension payments to the currently retired or issuance of earmarked debt and a corresponding relaxation of the debt ceilings established by the Stability and Growth Pact.

Even if the growth rate of labour productivity remains well below the rate of return on capital, a transition from PAYG to full funding cannot be beneficial to everybody. It must, inevitably, imply some loss for the generations currently alive. Careful analysis shows that the benefits will accrue only to generations not yet born. Such a reform is not politically feasible.

Moreover, a PAYG system, even if smaller than at present, is necessary for achieving intergenerational efficiency and fairness and to sustain long run growth, at least while we do not find means better than public expenditure for financing the accumulation of human capital.

A PAYG system is also necessary for beneficial portfolio diversification. The optimal relative size of the two systems (PAYG and funded), and the generosity of the PAYG system, can be calculated using historical evidence and standard economic theory. 
The historical experience of unfunded pension schemes in Europe reminds us of the wisdom of distinguishing 'market completing' from 'redistributive' policies. PAYG pension plans are public institutions aimed at alleviating inefficiencies generated by the lack of particular financial markets. Their use has camouflaged redistribution, motivated by rent seeking and political purposes, has turned into an abuse, and has brought the systems close to financial bankruptcy.

In the justifiable and commendable process of getting rid of such distributional distortions, one does not want to 'throw the baby out with the bath water'. PAYG public pensions serve a useful purpose, which should be salvaged and enhanced by a deeper reform of the European welfare state.

\section{Discussion}

\section{Friedrich Breyer \\ Universität Konstanz}

This is a very timely and important paper because the sustainability of public pension systems is an urgent policy issue in most European countries. I also agree with most of the authors' analysis and conclusions. However, there are two points where I would place the emphasis slightly differently:

- the relative importance of demographic and labour market factors in explaining the problems in future pension financing; and

- the relative advantages of different speeds of transition from the predominantly PAYG system to a mixed system of pension financing.

\section{Demographic and labour market determinants of the pension financing crisis}

Two different aspects of demographic change are important in explaining the difficulties in pension financing across Europe: a massive increase in residual life expectancy at age 60 (or 65), and a rapid decline in net reproduction rates. The first raises the tax rate necessary to finance a given earnings replacement rate, but it does so no matter whether the financing method is funding or PAYG. The policy recommendation for dealing with this phenomenon is simple: raise the retirement age so as to leave the relative length of the retirement period in adult life constant, or cut pension benefits in reverse proportion. Either method assures that the relative positions of the respective generations (their discounted net payments into or receipts from the pension system) remain unchanged when compared to the situation before the demographic change.

In contrast, a decline in fertility holding constant the long run paths of the rates of interest and productivity growth unilaterally decreases the rate of return of unfunded pension systems and raises questions of intergenerational redistribution. A simple look at the development of the net reproduction rates in Europe between 1970 and 1995 
(Eurostat, 1996) shows a dramatic change, which is not so transparent in the fertility rate differences stated by the authors in Table 2. While in 1970, the average net reproduction rate in the EU15 was 1.13 (with a maximum value of 1.81 in Ireland and a minimum of 0.87 in Finland, the average for 1994 was 0.69 (with 0.90 in Finland and Sweden and 0.58 in Italy and Spain). These figures alone show that, abstracting from massive migration, the relation between tax rates and benefit rates in any PAYG system will deteriorate on average by more than one half.

Compared to these secular changes, variations in labour force participation can have at most short run effects. First of all, in a PAYG system a given pension burden must be fully borne by the subsequent generation no matter whether this generation chooses to work little (and pay a high contribution rate) or much (and pay a smaller tax rate per unit of income). Therefore it is an illusion to think that the burden itself was alleviated through a decline in the tax rate. Moreover, in most pension systems, the benefits of an individual are related to his or her total lifetime earnings. As a consequence, increasing present labour force participation will raise the benefit claims of the current workers, which have to be met by the next generation, thus aggravating the financing problems in the future (Breyer et al., 1997).

Hence I would place the main emphasis on the demographic development and would be hesitant to expect any alleviation from increasing labour force participation rates.

\section{Partial transition to funded pensions}

Here, the authors are somewhat vague in their policy conclusions. On the one hand, they are in favour of a mixed pension system composed of funded and unfunded parts. On the other hand, they claim that all generations currently alive would suffer from a transition to such a system.

Taking the results in Breyer (1989) and Fenge (1995) seriously, it is certainly true that a transition from pure PAYG even to a mixed system (let alone pure capital funding) cannot make every generation better off. Thus, the matter boils down to a question of intergenerational redistribution, and here the economist should be extremely careful with policy recommendations.

Leaving the normative issue aside, the political feasibility of such a transition is certainly an interesting object of positive economics, and here the authors are much more explicit. In their view, because the political viability of a drastic transition is quite low, policies to spread costs and benefits in a homogeneous way across generations should be designed.

On this point, I am not so sure that they are right. After all, again taking the theoretical literature seriously, what is to be spread across generations are just costs and no benefits. Now it is certainly true for majority decisions that it is easier to make some (minority) group suffer a lot than to make everybody suffer a little. If this general message is applied to generations, a proposal that would harm the generation of present pensioners by cutting PAYG financed pensions immediately and drastically may have 
only a small chance of surviving a majority vote, and whether it does so should depend on the degree of altruism within families. However, a proposal to cut pensions by small bits over a long transition period (possibly using explicit public debt as a camouflage), thereby harming all living generations and perhaps one or two subsequent unborn ones on top, will by all received theories of public choice not draw support from any present voter and is therefore politically even less viable.

\section{Raquel Fernández}

\section{New York University}

This paper is composed of two distinct parts. The first describes trends in public pension provision in the EU, and attempts to simulate the effects of changes in labour market conditions on the overall fiscal burden. The second presents a theoretical justification for retaining at least some publicly funded pay as you go pension scheme.

The authors begin by describing the current state of public pension provision in the EU, and the expected impact of demographic changes over the next 50 years. Holding other factors constant unemployment and labour force participation demographic trends will make the fiscal burden of these schemes rise sharply, more than doubling in most cases to levels of 20 to $30 \%$ of GDP. It is generally agreed that the tax increases implied by such a burden are likely to be politically and economically unsustainable. The contribution of the paper is to quantify the contribution that non demographic factors the level of unemployment, female labour force participation, the generosity of the pension system might make towards offsetting these increases.

The single most interesting point is the potentially large effect of changes in labour market conditions. Increasing female labour force participation, and reducing male unemployment by half, would mitigate the increase in the fiscal burden by a third to a half. Similar reductions could be achieved by freezing the level of pensions, once awarded, in real terms. ${ }^{6}$ Combining these two changes would cut the increase resulting from the demographic burden by more than half, and further apparently minor reductions in the generosity of pensions could almost eliminate it.

The problem, however, with all these simulations (even leaving aside their partial equilibrium nature) is that they abstract away from the detailed provisions of the pension schemes, assuming instead, in the baseline case, that the average pension grows in line with average labour productivity. This in turn creates two problems. First, in the case of the proposed changes to the generosity of pension schemes, it makes it rather difficult to assess the political viability of the proposed policy changes. What changes would actually be needed to the rules of the Spanish pension system, for example, to freeze on average the levels of pensions once awarded? Second, in the case of the changes in labour market behaviour, it abstracts away from the fact that such changes would, given the nature of

\footnotetext{
${ }^{6}$ Somewhat confusingly, the authors distinguish between a policy of constant 'generosity', where newly awarded pensions are related to the level of labour productivity at the time they are awarded, but subsequently fixed in real terms, and a policy of constant 'Generosity', where even subsequent to retirement their value is increased in line with labour productivity.
} 
contribution related pension schemes, affect the level of pensions. If female labour force participation increased (and male unemployment decreased), that would indeed increase social security contributions and hence make schemes more solvent; this is the effect quantified in the paper. However, since these extra workers would be accumulating pension entitlements themselves (rather than being dependent on their husbands' pensions, or some basic minimum), pension expenditures would be increased. This effect is not quantified and would to some extent offset the first.

Nevertheless, these results are likely to be a useful guide for policy makers. They are a helpful reminder that demography is not destiny, and that the more apocalyptic predictions about 'Europe's unfunded pension burden' are overdone. Numerous available policy instruments could make a substantial contribution to saving Europe's publicly funded pension schemes in something resembling their present form. The authors are quite correct in their descriptions of the practical problems involved in any major switch to a funded scheme: data they present on stock returns, showing real returns averaging between $0.8 \%$ (Germany) and 5.5\% (Japan), indicate why the statement in the introduction that 'the growth rate of the market value of private investments has been ... 10\% a year in real terms in the EU ... and is not expected to drop in the future' is wholly unrealistic. ${ }^{7}$ Since much of the momentum behind the proposals for funded pension schemes is based on the argument that stock market returns will inevitably outpace earnings growth, this is an important point.

Switching tack completely, the second part of the paper moves from a description of the current pay as you go systems in Europe to a theoretical argument in favour of pay as you go pension provision. Briefly, the argument is that pay as you go systems can provide a means of financing investment in human capital, and in particular that part of human capital investment basically primary and secondary education for which functioning credit markets are largely absent. The uncertainty of future returns especially to investments financed by financial instruments strengthens the case for publicly financed investment in human capital. In itself, this argument is clearly sound. In the context of this paper, the unanswered question is, of course, how well designed public pension schemes actually are to achieve this objective. In another paper, one of the authors finds that the Spanish system requires 'on average' only minor adjustments.

However, this 'on average' is a major caveat, and points up a significant problem with both this part of the paper and the policy recommendations. The authors seem to regard it as inappropriate for publicly funded pension schemes to contain any redistributional element, arguing that 'PAYG pension plans are public institutions aimed at alleviating inefficiencies generated by the lack of certain financial markets. Their use has camouflaged redistribution motivated by rent seeking and political purposes [and] has turned into an abuse ...'. As a positive statement, this is simply wrong. PAYG pension plans were introduced first to alleviate the unacceptable level of poverty among the

\footnotetext{
${ }^{7}$ It is not clear whether the authors endorse this statement or regard it as part of the 'conventional wisdom'.
} 
elderly that resulted from the creation of an urban industrial proletariat and the associated breakdown of the extended family. They were then expanded as part of the postwar European (and American) social bargain. ${ }^{8}$ Both of these purposes were and remain explicitly redistributional. Whether this is the appropriate way for the government to redistribute is another question. It may, in any case, be one of the few politically acceptable ways to do so.

\section{General discussion}

Peter Birch Sørensen observed that, in order to assess the proposal to freeze pension generosity, it would be helpful to spell out the effect of this reform on the path of future replacement ratios once the pensions profile after retirement was no longer indexed to productivity. Katharine Rockett extended this implicit concern about political feasibility. What would happen if an individual decided not to contribute? How would government respond if poverty in pensions was the result not of bad luck, but of deliberate neglect of the individual need to save? Deeper analysis of political economy aspects would greatly enhance the appeal of particular hypothetical policy simulations.

Stephen Nickell noted that the measures to reduce labour supply and massage unemployment data in ways favourable to politicians often had the consequence of increasing the social security burden; measures to promote early retirement or sickness benefits obviously fell into such a category. Pension reform should therefore attempt to take a comprehensive view of social security policy design. Jakob de Haan was sceptical about one of the scenarios of the paper, in which it was assumed that it was possible both to reduce unemployment and to have rapid productivity growth. Dutch experience showed that higher participation rates were often accompanied by lower rates of productivity growth and of earnings. Marco Pagano wondered to what extent the paper has taken into account the potential problem of increasingly high inter European immigration flows.

Alan Timmermann argued that the policy recommendation to have a mixed pension system should be strengthened by providing more evidence to support it. To the extent that the recommendation was based on the fact that the PAYG system incorporated components not captured by funded schemes in the presence of incomplete markets, one could examine the factors underlying the whole set of traded assets, say in the USA, and analyse incompleteness directly.

David Begg remarked that most economics suggests that we should target interventions at the source of the problem. In this case, the source of the problem is the demographic change. In this respect, not only should birth rates be treated as

\footnotetext{
${ }^{8}$ It should not be forgotten that, while the European welfare state is overall substantially more generous than the US one, the contrast is not nearly so great in the specific area of public provision for old age. In particular, the US social security system has largely eliminated poverty among the elderly, while doing relatively little for poor children.
} 
endogenous, as recent evidence from eastern Europe demonstrates, but also more emphasis should be given to the retirement age, which because of the policy makers' inertia has not been raised. Changing the ratio of work years to (expected) years in retirement might be politically easier than changing the generosity of the annual replacement rate.

The authors offered several responses to the Panel discussion. Firstly, under the current pension system, internal rates of return are very high, making the current system unsustainable. Some change to PAYG was needed. The PAYG system was designed in a period in which typically, in the representative household, only the man was working, whereas today the household participation rate has increased, and the composition of households themselves has changed. This in itself provided a rationale for amending the parameters of the existing system, and such changes should be explored before concluding that a completely new system is required. Finally, as far as political viability is concerned, calculations for Spain indicated that, if some reform were undertaken, sustainability could be restored without abandoning the PAYG system as the basis of pensions.

\section{APPENDIX}

Table A1. Institutional features of European pensions

\begin{tabular}{|c|c|c|c|c|c|c|c|}
\hline & \multicolumn{4}{|c|}{ Public PAYG scheme } & \multicolumn{2}{|c|}{$\begin{array}{l}\text { Pensions from } \\
\text { employers }\end{array}$} & \multirow{3}{*}{$\frac{\text { Private pensions }}{\% \text { of GDP }}$} \\
\hline & \multicolumn{2}{|c|}{ Flat rate } & \multicolumn{2}{|c|}{ Earnings related schemes } & \multirow{2}{*}{$\begin{array}{c}\text { Coverage } \\
(\%)\end{array}$} & \multirow[t]{2}{*}{$\%$ of GDP } & \\
\hline & & & $\begin{array}{l}\text { Benefit related } \\
\text { contributions }\end{array}$ & $\begin{array}{l}\text { Special } \\
\text { schemes }\end{array}$ & & & \\
\hline Austria & yes & MT & yes & yes & & & \\
\hline Belgium & yes & MT & yes & yes & 31 & 3 & 11 \\
\hline Denmark & yes & MT & yes & no & 80 & 20 & 84 \\
\hline Finland & yes & MT & no & yes & & & 35 \\
\hline France & yes & MT & yes & yes & $<10$ & 3 & 7 \\
\hline Germany & no & & yes & yes & 46 & 6 & 14 \\
\hline Greece & no & & yes & yes & & & \\
\hline Ireland & yes & MT & no & no & 40 & 40 & \\
\hline Italy & yes & MT & yes & yes & 5 & 1 & 7 \\
\hline Netherlands & yes & & no & no & 85 & 89 & 127 \\
\hline Portugal & yes & MT & yes & yes & 15 & & 9 \\
\hline Spain & yes & MT & yes & yes & 15 & 2 & 4 \\
\hline Sweden & yes & & yes & no & & & 66 \\
\hline UK & yes & & no & no & 75 & 79 & 77 \\
\hline
\end{tabular}

Source: US Dept of Health and Human Resources (1998).

Note: MT is means tested, coverage is \% of private employment in early 1990s, shares of GDP refer to 1993 data, private pensions include funded pensions provided by employers. 
Table A2. Public earnings-related pensions in sample of countries, mid-1990s

\begin{tabular}{|c|c|c|c|c|c|c|c|c|c|}
\hline & \multirow{2}{*}{\multicolumn{2}{|c|}{$\begin{array}{l}\text { Contribution } \\
(\%)\end{array}$}} & \multicolumn{3}{|c|}{ Eligibility } & \multicolumn{2}{|l|}{ Pension } & \multirow[t]{3}{*}{ Indexed to } & \multirow{3}{*}{$\begin{array}{l}\text { Widow's } \\
\text { benefit }\end{array}$} \\
\hline & & & \multirow{2}{*}{$\begin{array}{l}\text { Age } \\
(\mathrm{M}, \mathrm{W})\end{array}$} & \multirow{2}{*}{$\begin{array}{l}\text { Contribution } \\
\text { years }\end{array}$} & \multirow{2}{*}{$\begin{array}{c}\text { Early } \\
\text { retirement } \\
(\mathrm{M}, \mathrm{W})\end{array}$} & \multirow{2}{*}{ Benefits } & \multirow{2}{*}{ Maximum } & & \\
\hline & Worker & Firm & & & & & & & \\
\hline Aust & 10.25 & 12.55 & 65,60 & 15 of last 30 & 60,55 & $\begin{array}{l}1.83 \% \text { earnings in best } 15 \text { years of first } 30 \\
\text { years } \\
+1.675 \% \text { for each year } 3145\end{array}$ & $\begin{array}{l}80 \% \text { of average covered } \\
\text { earnings; } \\
60 \% \text { if early retirement }\end{array}$ & Wages & $40 \quad 60 \%$ \\
\hline Belg & 7.5 & 8.86 & 65,61 & $45(\mathrm{M}), 41(\mathrm{~W})$ & & Based on salary and length of work & $\begin{array}{l}6075 \% \text { average lifetime } \\
\text { earnings }\end{array}$ & CPI & $80 \%$ \\
\hline Denm & $\begin{array}{l}33.3 \\
\text { of } \max \\
\text { kro }\end{array}$ & $\begin{array}{l}66.7 \\
\text { of } 2332 \\
\text { oner }\end{array}$ & 67 & & 5066 & Based on entry date and contributions & $\begin{array}{l}13500 \text { kroner p.a. } \\
\text { (if work } 40 \text { years) }\end{array}$ & Wages & Lump sum \\
\hline Fin & 4.5 & 16.6 & 65 & 40 & 60 & $\begin{array}{l}1.5 \% \text { per year worked ( } 2.5 \% \text { after age } 59) \\
\text { Average wage in } 2 \text { of last } 4 \text { years (eliminating } \\
\text { highest and lowest) }\end{array}$ & $60 \quad 70 \%$ & CPI & up to $50 \%$ \\
\hline Fra & $\begin{array}{r}6.55 \\
+\mathrm{GSC} \\
\text { total }\end{array}$ & $\begin{array}{l}\quad 8.2 \\
\& 1.6 \% \\
\text { payroll }\end{array}$ & 65 & 37.5 & 60 & $50 \%$ of highest 10 years & $50 \%$ & CPI & $52 \%$ \\
\hline Ger & 10.15 & 10.15 & 65,60 & at least 5 & 60 & $\begin{array}{l}\text { (earnings/avge earnings) } \times(\text { years }) \\
\times 46 \mathrm{DM} / \text { month }\end{array}$ & $70 \%$ (after 45 years) & Wages & $\begin{array}{l}60100 \% \\
3 \text { months } \max \end{array}$ \\
\hline Gre & $<8.87$ & $<14.73$ & 65,60 & 4500 days & 58,50 & $3070 \%$ earnings in last 5 years & & $\begin{array}{l}\text { Pensions of } \\
\text { civil servants }\end{array}$ & $70 \%$ \\
\hline Ire & $<7.75$ & $<12.2 \%$ & 66 & 156 weeks & & 71116.5 punts/week & & & $\begin{array}{l}64.5 \\
\text { punts/wk }\end{array}$ \\
\hline Ita & 6 & 24.5 & 63,58 & & 50 & $1.62 \%$ of average lifetime earnings & & CPI & $60 \%$ \\
\hline Net & 16.35 & & 65 & & & 19882860 guilders (couple); 1430 (single) & & Minimum wage & $\begin{array}{l}17552040 \\
\text { guilders }\end{array}$ \\
\hline Por & 7.7 & 16.7 & 65 & 180 months & 60 & $\begin{array}{l}2 \% \text { of earnings per year; average annual } \\
\text { earnings during highest } 10 \text { of last } 15 \text { years }\end{array}$ & $80 \%$ & CPI & $60 \%$ \\
\hline Spa & 4.7 & 23.6 & 65 & 15 & 60 & $\begin{array}{l}3.5 \% \text { (first } 15 \text { years) }+2.5 \% \text { (rest); } \\
\text { average of last } 15 \text { years }\end{array}$ & $100 \%$ (after 35 years) & CPI & $45 \%$ \\
\hline Swe & & 13.0 & 65 & 30 & 60 & $60 \%$ (average of last 15 years) & & Wages & $40 \%$ \\
\hline UK & $<10$ & $<10$ & 65,60 & & & $£ 58.85 /$ wk + supplement & & CPI & $£ 58.85 / w k$ \\
\hline US & 6.2 & 6.2 & 65 & & 62 & Based on lifetime earnings & $\$ 2099 /$ month & CPI & $\widetilde{100 \%}$ \\
\hline Jap & 8.67 & 8.67 & 60,59 & 25 & 60 & $0.75 \%$ times months worked & & CPI & \\
\hline
\end{tabular}

Source: US Dept of Health and Human Resources (1998). 


\section{REFERENCES}

Bank for International Settlements (BIS) (1998). The Macroeconomic and Financial Implications of Ageing Populations: A Report by the Group of Ten, Basel.

Blöndal, S. and S. Scarpetta (1998). 'Falling participation rates among older workers in the OECD countries: the role of social security systems', OECD, Paris.

Boldrin, M. and A. Montes (1998). 'Intergenerational transfer institutions: public education and public pensions', mimeo, Universidad Carlos III de Madrid.

Breyer, F. (1989). 'On the intergenerational Pareto efficiency of pay-as-you-go financed pension systems', Fournal for Institutional and Theoretical Economics.

Breyer, F., M. Kifmann and K. Stolte (1997). 'Rentenzugangsalter und Beitragssatz zur Rentenversicherung', Finanzarchiv.

Davis, E.P. (1998). 'Pension fund reforms and European financial markets', Financial Markets Group, Special Paper no. 107.

Diamond, P. (1977). 'A framework for social security analysis', Journal of Public Economics.

Diamond, P. (1997). 'Macroeconomic aspects of social security reform', Brookings Papers on Economic Activity.

European Commission (1997). Supplementary Pensions in the Single Market, Office for Official Publications of the European Communities, Luxembourg.

Eurostat (1996). Demographic Statistics 1996, Office for Official Publications of the European Communities, Luxembourg.

Feldstein, M. (1995). 'Would privatizing social security raise economic welfare?', NBER Working Paper no. 5281.

Feldstein, M. (1996). 'The missing piece in policy analysis: social security reform', American Economic Review Papers and Proceedings.

Feldstein, M. (1999). 'America's golden opportunity', The Economist, 13 March.

Feldstein, M. and A. Samwick (1998). 'The transition path in privatizing social security', in M. Feldstein (ed.), Privatizing Social Security, University of Chicago Press, Chicago, IL.

Fenge, R. (1995). 'Pareto-efficiency of the pay-as-you-go pension system with intragenerational fairness', Finanzarchiv.

Gruber, J. and D. Wise (eds.) (1998). Social Security and Retirement Around the World, University of Chicago Press, Chicago, IL.

Holzmann, R. (1997). 'On economic benefits and fiscal requirements of moving from unfunded to funded pensions', European Economy Reports and Studies.

Kotlikoff, L. (1995). 'Privatization of social security: how it works and why it matters', NBER Working Paper no. 5330.

Kotlikoff, L. (1996). 'Privatizing social security at home and abroad', American Economic Review Papers and Proceedings.

Merton, R. (1983). 'On the role of social security as a means for efficient risk sharing in an economy where human capital is not tradeable', in Z. Bodie and J. Shoven (eds.), Financial Aspects of the United States Pension System, University of Chicago Press, Chicago, IL.

Miles, D. (1999). 'Modelling the impact of demographic change upon the economy', Economic fournal.

Miles, D. and A. Iben (1998). 'The reform of pension systems: winners and losers across generations in the UK and Germany', mimeo, Imperial College.

Miles, D. and A. Timmermann (1999). 'Risk sharing and transition costs in the reform of pension systems in Europe', Economic Policy, this issue.

Mitchell, O. and S. Zeldes (1996). 'Social security privatization: a structure for analysis', American Economic Review Papers and Proceedings.

Montes, A. (1998). 'Education and pensions: looking deeper into the mechanisms of the welfare state', Ph.D. dissertation, Universidad Carlos III de Madrid.

Roseveare, D., W. Leibfritz, D. Fore and E. Wurzel (1996). 'Ageing populations, pension systems and government budgets: simulations for 20 OECD countries', OECD Economics Department Working Paper no. 168.

Samuelson, P. (1975). 'Optimum social security in a life-cycle growth model', International Economic Review.

US Department of Health and Human Resources (1998). Social Security Programs Throughout the World, Washington, DC.

World Bank (1994). Averting the Old Age Crisis: Policies to Protect the Old and Promote Growth, Washington, DC. 